\title{
Design of Game-Based Collaborative Learning Model
}

\section{Qi Zhong}

School of Educational Science, Nanjing Normal University, Nanjing, China

Email: 170602150@stu.njnu.edu.c

How to cite this paper: Zhong, Q. (2019)

Design of Game-Based Collaborative Learning Model. Open Journal of Social Sciences, 7, 488-496.

https://doi.org/10.4236/jss.2019.77039

Received: June 16, 2019

Accepted: July 28, 2019

Published: July 31, 2019

Copyright (C) 2019 by author(s) and Scientific Research Publishing Inc. This work is licensed under the Creative Commons Attribution International License (CC BY 4.0).

http://creativecommons.org/licenses/by/4.0/

\begin{abstract}
Collaborative learning mode has changed the traditional teaching mode, In the process of completing tasks, learners learn new knowledge points in the form of team cooperation, rather than relying on a large amount of knowledge inculcated by teachers, which helps to improve learners' thinking ability, communication ability and team cooperation ability. Game-based learning is a kind of instructional design which combines the design strategies of games. It enables learners to complete the learning content in a game-based way with a relaxed and pleasant environment. It helps to cultivate learners' initiative, creativity and cooperation in learning. Based on the above two concepts, this paper proposes a game-based cooperative learning teaching model, which has a clearer design and guidance for the teaching model.
\end{abstract}

\section{Keywords}

Game-Based, Collaborative Learning, Teaching Mode, Teaching Design

\section{Introduction}

Cooperative Learning (CL) was proposed by the Johnson Brothers of the Cooperative Learning Center of the University of Minnesota in the early 1960s and made substantial progress from the mid-1970s to the mid-1980s [1]. In the form of group or team, learners cooperate and help each other in order to achieve the greatest learning outcomes under the common goals and certain incentives [2]. In this process, learners' thinking ability, communication ability, collective sense and tolerance ability between different individuals are exercised.

The learning effect of collaborative learning depends on the joint efforts of team members who have a strong positive dependence. Task-driven and appropriate division of labor can ensure that team members actively participate and share resources [3]. Rotation of roles can promote the development of students 
in different aspects. Sharing leadership responsibility can enable each student to participate actively. It can not only ensure students' mutual assistance and cooperation, but also give them the opportunity to give full play to their abilities [4]. The most effective learning effect comes from meaningful situations which can give full play to learners' subjective initiative and improve learning efficiency [5]. For students, interest is an important factor affecting learning effectiveness. The reason why games are attractive is that games cannot be separated from real situations, and their role-playing and task-driven are also important reasons for attracting games [6]. For this reason, many experts put forward the integration of education and games to achieve the goal of "teaching and entertainment".

\section{Game-Based Learning Definition}

Piaget's game-based learning theory [7] which derived from Piaget's cognitive development theory. Piaget believes that children's development is accomplished by the process of assimilation-adaptation. Children's psychology (Piaget calls it intelligence) does not originate from innate maturity, nor from acquired experience, but from the action of the subject. The essence of this action is the adaptation of the subject to the object. Individual adaptation achieves the balance between organism and environment through assimilation and adaptation. Assimilation refers to a situation in which a child uses the schema or skill he has acquired to engage in and complete activities. Adaptation is when children try new schemas or skills to achieve certain goals. The coordination or balance between assimilation and adaptation is the adaptation of knowledge and the essence of human wisdom. In Piaget's view, games are the way to learn new things, the way to form and expand knowledge and skills, the way to combine thinking and action, and the important means of children's intellectual development. He also believes that the main reason why learners play games is that there is a stage for them to try without any responsibility and punishment. In this process, learners can consolidate the newly acquired cognitive structure and develop their emotional experience [8].

Game-Based Learning, translated by Taiwanese researchers as fun-based learning, is an innovative teaching method that integrates education and play. By closely linking educational games with teaching content and creating game-based learning situations, students can complete game tasks independently in the form of individual or group collaboration in the interesting and challenging game scenarios. Thus, learners can complete the construction of knowledge, enhance the ability of collaboration and problem solving in the course of the game. In the process of game-based learning, stimulated learning motivation can enhance students' interest in learning knowledge. This is a learning method of "play-and-learn" that learning is integrated into the game [9]. Combine the elements of learning in the game, such as motivation, interest, curiosity, challenge and feedback, with the learning content, so as to achieve the learning effect as easy and devoted as playing the game. 


\section{Collaborative Learning Definition}

Collaborative learning is a learning strategy under the guidance of constructivist learning theory which embodies the cognitive tools, social construction and cognitive sharing advocated by constructivism [10]. Zhao Jian hua and $\mathrm{Li} \mathrm{Ke}$ dong believe that collaborative learning is a strategy to organize students to learn through groups or teams, and classify it carefully. The basic modes of collaborative learning include competition, debate, cooperation, problem solving, partner, design and role playing [11]. In this way, learns feel that they are no longer competitors, but helpers to promote learning. Fang Yun duan analyzed the basic elements of task-driven collaborative learning model, and constructed a new education model with teachers as the leading role and students as the main body, which can cultivate students' innovative ability, exploratory spirit and cooperative learning consciousness [12]. Cooperative learning model can mobilize learners' enthusiasm, develop learners' individual thinking ability and establish learners' collective sense of honor [13]. In addition, the teaching effect of collaborative learning mode is much higher than that of traditional teaching. It can not only improve students' academic performance, cultivate students' critical thinking and innovative thinking ability, but also play a positive role in cultivating learners' communication ability, respect for each other and listen to each other's opinions modestly [14]. Han-Yu Sung a, Gwo-Jen Hwang found that in a collaborative game-based learning environment, primary school students share and organize knowledge while playing games in natural science classes, which not only promotes their learning attitude and motivation, but also improves their academic performance and self-efficacy [15]. Marina Papastergiou found that in high school computer science curriculum, compared with traditional teaching, game-based learning can promote students' knowledge acquisition and motivation. Many scholars have confirmed through empirical research that game-based collaborative learning can really stimulate students' motivation, and has great potential in improving students' academic performance.

\section{Instructional Design Game-Based Collaborative Learning}

$\mathrm{n}$ the course of the operation of cooperative learning classes, teachers are freed from the process of knowledge imparting and become facilitators and guides of learning [16]. This doesn't mean that the role of teachers is declining, on the contrary, teachers are more responsible. In the cooperative learning classroom, teachers should analyze the learning content and learning objectives in advance and transform them into related problems for better integrate the problems and situations to stimulate students' interest, group students in heterogeneous groups form a good organizational structure. In the course, students need to master subject knowledge through independent exploration and cooperative learning, and cultivate their ability of independent thinking and teamwork [17]. Before the end of the course, teachers should give feedback and summary according to students' classroom performance which can urge students to think 
further about knowledge and learning process, consolidate knowledge, improve thinking methods and improve learning ability. When applying the concept of game-based learning to the cooperative learning model classroom, teachers need to integrate various game-based learning design strategies into the design factors of cooperative learning teaching on the basis of mastering the concept of game-based learning design proficiently, so as to achieve the perfect integration of the two. The following will discuss how game-based learning design strategy meets the design needs of cooperative learning model classroom (see Table 1). Taking the knowledge points of "on-site arrangement" in the knowledge module of enterprise annual meeting in the textbook "Business Activity Planning and Operation" of a tourism vocational school as an example, this paper introduces in detail the current design strategy. "Site layout" comprehensive assessment of student activity execution ability a high practical value in the future work, including the layout of goods, material selection, as well as decoration site requirements and rules. The teaching process is mainly to create task situations by means of educational games and accomplish tasks by means of teamwork learning.

\subsection{Target Stratification}

Game-based learning will change the traditional idea of "teacher-centered" so that learners can actively construct their own knowledge system in teaching activities. The stratification of objectives enables students to choose appropriate content according to their level. Higher-level students deepen their knowledge and achieve more goals in a certain period of time, while lower-level students can do as they can and improve on the basis of consolidating their original knowledge. For example, at the initial level, students only need to complete the site layout of a certain item, which is the completion of a single knowledge point. As the difficulty of the level escalates, students need to design their own layout of the scene, put more items.

Table 1. The relationship between the design strategy and teaching strategies in game-based collaborative learning model.

\begin{tabular}{lll}
\hline $\begin{array}{l}\text { Design Strategy } \\
\text { Target }\end{array}$ & Teaching Design & Examples \\
stratification & $\begin{array}{l}\text { Analysis of learning content and } \\
\text { clarification of learning objectives at all levels }\end{array}$ & Upgrade \\
Game level & Knowledge fragmentation and learning motivation & Rush through customs \\
Game scene & $\begin{array}{l}\text { Learning environment Design and learning } \\
\text { motivation }\end{array}$ & $\begin{array}{l}\text { Background Display of } \\
\text { Task Situation }\end{array}$ \\
$\begin{array}{l}\text { Role assignment } \\
\text { foedback }\end{array}$ & Division of labour among study group members & Role selection \\
Team work & Learning support & Voice communication \\
$\begin{array}{l}\text { Reflections on } \\
\text { evaluation }\end{array}$ & Team evaluation and course summary & Role Tasks, Team Tasks \\
\hline
\end{tabular}




\subsection{Game Level}

The design of game level is based on Scaffolding Teaching mode [18]. In game-based learning, knowledge points are not suitable for students to present directly. Usually, they need to dress up as different small tasks. Each task includes a small knowledge point to transform into a problem situation, that is, to create one or more scenarios which needed to be solved. The learners can comprehend the task of constructing knowledge games according to specific scenarios [19]. In the process of completing the task, learners will encounter problems, explore problems, solve problems, encounter new problems and continue to explore solutions, so that the whole system can run and promote learners from the "first pass" to the completion of "customs clearance". For example, when examining students' knowledge of materials, the environment provides information about the use and location of the table to determine the size and material of the selected table.

\subsection{Game Scene}

The design of game situation is based on anchored teaching mode [20]. Knowledge points are contained in game situations and are life-oriented, which makes the mastery of knowledge no longer a theoretical understanding, increases the connection with real life, and makes learners easier to understand and accept [21]. Game-based situations can create a good learning atmosphere and help to establish a harmonious relationship between learners and teachers. Student learning with interest and pleasant mood can not only improve efficiency, but also deepen the memory of knowledge [22]. For example, role-playing is performed by teachers. As a guest, detailed information can help students to think more thoroughly and turn knowledge into practical skills.

\subsection{Role Assignment}

In the process of learning, learners study knowledge and understand it through role-playing in a social situation, and use existing knowledge and life experience to solve problems in learning, so as to realize the infiltration of subject knowledge into life [23]. Of course, they can switch roles from one another. Through role-playing, learners will have a new understanding of the problem. The success of role playing can increase learners' sense of achievement and responsibility, and stimulate interest and enthusiasm in mastering knowledge [24]. For example, students play different roles, such as customers, designers, purchasers, implementers, etc. to consider different factors that need to be considered in different positions.

\subsection{Communication Feedback}

In the process of game-based learning, learners need a space for free communication to accumulate their own learning experiences and perceptions for others from experience; learners can also seek help and share experience in this space. 
Communication can help learners to solve practical problems encountered in the process of games to improve game strategies, and make learners study from each other. Feedback of accurate information can help learners to find shortcomings in the process of games, correct and make up for them to improve learning efficiency and enhance learning confidence at the same time [25]. In some game activities in the classroom, direct face-to-face communication may achieve the desired effect. However, in some games, real-time online communication may be more convenient and effective. Computer, ipad and other electronic devices are stationed in the classroom, which provides good support. In the whole game process, the different roles of students need to constantly communicate and adjust the site layout to achieve the final satisfactory results.

\subsection{Team Work}

In order to achieve common goals, learners form a team and develop their strengths, division of labor and cooperation, learn from each other's strengths and make up for each other's weaknesses. The learners' spirit of cooperation and sense of collective honor are cultivated. Because the problems to be solved are complex, participants can rely on team strength to solve them. There are complex cognitive communication and cognitive collaboration between them [26]. Learners can discuss and negotiate issues of common concern and get ideas from each other for problem solving. The relationship between learners is generally harmonious, but it may also generate controversy for the solution of a certain problem. All kinds of viewpoints can complement each other and reach consensus in the controversy so as to complete the learning task satisfactorily. Site layout is a complex process, different roles will put forward different angles of thinking about the problem. For example, the designer will think from the final layout effect, and the purchaser will think from the choice of materials.

\subsection{Reflections on Evaluation}

Evaluation needs to run through the whole process of the game, and process evaluation plays a very good guiding role for learners. When teachers evaluate the overall performance of learners in the whole game, they need to examine the learners' motivation, learning effectiveness, learning ability, collaborative ability, emotional value and other factors. In addition, when deciding the learner's performance, teachers should not make a "one-word" decision, but refer to the opinions of students themselves, teams, competitors and other directions. In determining the final winner, teachers can organize award-giving activities and give certain prizes to make the learning process more attractive.

If teachers simply use games to complete the teaching process, they may not be able to achieve the ultimate teaching purpose. Reflections and summaries in the process or after the game are effective ways to ensure that knowledge is learned [27]. While summarizing and reflecting on their own operation process, learners construct and improve their own knowledge system. When teachers 
urge students to reflect, they must put it into words to form a series of reflective process.

\section{Summary}

The game-based learning concept is applied in the teaching process of collaborative learning. The imparting and internalization of knowledge are accomplished through classroom games. This teaching method enables students to complete their learning in a relaxed and pleasant environment, and improves their self-team awareness and collaborative ability. However, in practice, there are still some shortcomings and challenges in the process of implementing game-based learning, for example, how to ensure that students can truly participate in the process instead of completing tasks by others, how to enhance the interesting degree of educational games enough to attract students to immerse in the completion of tasks, how to effectively integrate educational knowledge points and game links so that students can master knowledge points rather than games.

Collaborative learning is an innovation of traditional teaching mode; the concept of game-based learning can well support the development of collaborative learning, which is more conducive to students' learning. However, good application in practice still needs researchers to explore in real teaching practice. For example, improving teachers' organizational ability is an important prerequisite for game-based collaborative learning, more diverse forms of game-based collaborative learning are also hot topics for further research, and a more natural combination of educational games and learning content is also worth exploring.

\section{Conflicts of Interest}

The author declares no conflicts of interest regarding the publication of this paper.

\section{References}

[1] Li, Q., Lau, R.W.H., Shih, T.K. and Li, F.W.B. (2008) Technology Supports for Distributed and Collaborative Learning over the Internet. ACM Transactions on Internet Technology, 8, Article No. 5. https://doi.org/10.1145/1323651.1323656

[2] Liu, G.Z., Chen, J. and Hwang, G.J. (2018) Mobile-Based Collaborative Learning in the Fitness Center: A Case Study on the Development of English Listening Comprehension with a Context-Aware Application. British Journal of Educational Technology, 49, 305-320. https://doi.org/10.1111/bjet.12581

[3] Li, K.M. (2015) Learning Styles and Perceptions of Student Teachers of Computer-Supported Collaborative Learning Strategy Using Wikis. Australasian Journal of Educational Technology, 31, 32-50.

[4] Du, H., Qi, Z., Tian, X. and Pan, Y. (2010) Web-Based INC Collaborative Learning Based on LAMS. International Conference on E-Business \& E-Government. 2010 International Conference on E-Business and E-Government, Guangzhou, 7-9 May 2010, 5594-5597.

[5] Herbst, P.G. (2006) Teaching Geometry with Problems: Negotiating Instructional Situations and Mathematical Tasks. Journal for Research in Mathematics Educa- 
tion, 37, 313-347.

[6] Yang, H., Wang, L. and Ma, R.X. (2006) Exploration of the Integration of Online Game and Education: A Preliminary Study of Game-Based Learning Community. Research on Audiovisual Education, 4, 43-46.

[7] Piaget, J. (1974) The Future of Developmental Child Psychology. Journal of Youth \& Adolescence, 3, 87-93 https://doi.org/10.1007/BF02215168

[8] Piaget, J. (2010) Part I: Cognitive Development in Children: Piaget Development and Learning. Journal of Research in Science Teaching, 2, 176-186. https://doi.org/10.1002/tea.3660020306

[9] Lee, H., Parsons, D., Kwon, G., Kim, J., Petrova, K., Jeong, E. and Ryu, H. (2016) Cooperation Begins: Encouraging Critical Thinking Skills through Cooperative Reciprocity Using a Mobile Learning Game. Computers \& Education, 97, 97-115. https://doi.org/10.1016/j.compedu.2016.03.006

[10] Rabbany, R., Elatia, S., Takaffoli, M. and Zaïane, O.R. (2014) Collaborative Learning of Students in Online Discussion Forums: A Social Network Analysis Perspective. In: Peña-Ayala, A., Ed., Educational Data Mining. Studies in Computational Intelligence, Springer, Cham, 441-466. https://doi.org/10.1007/978-3-319-02738-8_16

[11] Zeng, Y. and Zhang, L.-X. (2012) Implementing a Cooperative Learning Model in Universities. Educational Studies, 38, 165-173.

https://doi.org/10.1080/03055698.2011.598687

[12] Hui, M., Zheng, Z., Fei, Y. and Tong, S. (2010) The Applied Research of Cloud Computing in the Construction of Collaborative Learning Platform Under E-Learning Environment. 2010 International Conference on System Science, Engineering Design and Manufacturing Informatization, Yichang, 12-14 November 2010, 190-192.

[13] Van Ryzin, M.J. and Roseth, C.J. (2018) Cooperative Learning in Middle School: A Means to Improve Peer Relations and Reduce Victimization, Bullying, and Related Outcomes. Journal of Educational Psychology, 110, 1192-1201.

[14] Cheng, H.F., Yu, B., Park, Y.H. and Zhu, H. (2017) ProjectLens: Supporting Project-Based Collaborative Learning on MOOCs. In: Proceedings of the 2017 Fourth ACM Conference on Learning@ Scale, ACM, New York, 253-256. https://doi.org/10.1145/3051457.3053998

[15] Sung, H.-Y. and Hwang, G.-J. (2013) A Collaborative Game-Based Learning Approach to Improving Students' Learning Performance in Science Courses. Computers \& Education, 63, 43-51. https://doi.org/10.1016/j.compedu.2012.11.019

[16] Schroeder, S. (2011) Un-Standardizing Curriculum: Multicultural Teaching in the Standards-Based Classroom. Urban Education, 46, 880-887. https://doi.org/10.1177/0042085910377854

[17] Tao, S.Y., Huang, Y.H. and Tsai, M.J. (2017) Applying the Flipped Classroom with Game-Based Learning in Elementary School Students' English Learning. 2016 International Conference on Educational Innovation through Technology, Tainan, Taiwan, 22-24 September 2016, 59-63. https://doi.org/10.1109/EITT.2016.19

[18] Bliss, J., Askew, M. and Macrae, S. (1996) Effective Teaching and Learning: Scaffolding Revisited. Oxford Review of Education, 22, 37-61.

https://doi.org/10.1080/0305498960220103

[19] Papastergiou, M. (2009) Digital Game-Based Learning in High School Computer Science Education: Impact on Educational Effectiveness and Student Motivation. Computers \& Education, 52, 1-12. https://doi.org/10.1016/j.compedu.2008.06.004 
[20] P-Mar, V.N. (1993) Anchored Instruction and Situated Cognition Revisited. Educational Technology, 33, 52-70.

[21] Bottge, B.A., Rueda, E., Grant, T.S., Stephens, A.C. and Laroque, P.T. (2010) Anchoring Problem-Solving and Computation Instruction in Context-Rich Learning Environments. Exceptional Children, 76, 417-437. https://doi.org/10.1177/001440291007600403

[22] Sari, S., Anjani, R., Farida, I. and Ramdhani, M.A. (2017) Using Android-Based Educational Game for Learning Colloid Material. Journal of Physics: Conference Series, 895, Article ID: 012012. https://doi.org/10.1088/1742-6596/895/1/012012

[23] Batista, R. and Vaz de Carvalho, C. (2008) Work in Progress-Learning through Role Play Games. 2008 38th Annual Frontiers in Education Conference, Saratoga Springs, New York, 22-25 October 2008, T3C-7-T3C-8.

[24] Dado, M. and Bodemer, D. (2017) A Review of Methodological Applications of Social Network Analysis in Computer-Supported Collaborative Learning. Educational Research Review, 22, 159-180. https://doi.org/10.1016/j.edurev.2017.08.005

[25] Shi, Y., Bi, T. and Yang, W. (2012) Development of High Quality Educational Game by Information Technology Support. 2012 2nd International Conference on Consumer Electronics, Communications and Networks, Yichang, 21-23 April 2012, $1779-1782$.

[26] Sardone, N.B. (2018) Attitudes toward Game Adoption: Preservice Teachers Consider Game-Based Teaching and Learning. International Journal of Game-Based Learning, 8, 1-14. https://doi.org/10.4018/IJGBL.2018070101

[27] Vos, N., Meijden, H.V.D. and Denessen, E. (2011) Effects of Constructing versus Playing an Educational Game on Student Motivation and Deep Learning Strategy Use. Computers and Education, 56, 127-137.

https://doi.org/10.1016/j.compedu.2010.08.013 